\title{
"Brothers Gonna Work It Out:" Understanding the Pedagogic Performance of African American Male Teachers Working with African American Male Students
}

\author{
Anthony L. Brown
}

Published online: 15 May 2009

(C) Springer Science+Business Media, LLC 2009

\section{Erratum to: Urban Rev \\ DOI 10.1007/s11256-008-0116-8}

In the first footnote of the first page, the correct title of the song is "Brothers Gonna Work it Out".

The online version of the original article can be found under doi:10.1007/s11256-008-0116-8.

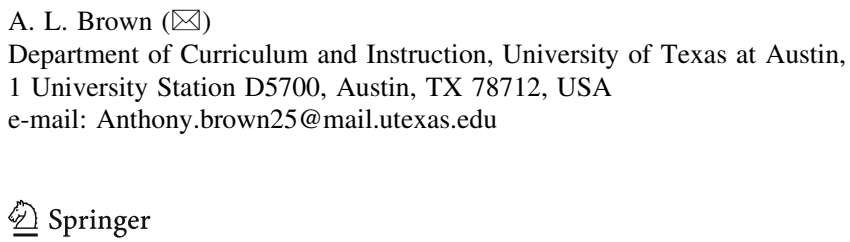

